\title{
Prevalence of vitamin D deficiency is higher in patients with Paget's disease of bone compared with age-matched controls
}

\author{
Deficiência de vitamina $D$ é maior em pacientes com doença \\ de Paget óssea comparada a controles pareados por idade
}

Luiz Griz', Francisco Bandeira', Erik Trovão Diniz',

Marcelo Cabral' ${ }^{1}$ Eduardo Freese ${ }^{2}$

\begin{abstract}
Objective: To investigate if vitamin D deficiency is more prevalent in patients with Paget's disease of bone (PDB) than in age-matched controls. Subjects and methods: We measured serum 25-OHD in 28 untreated patients with PDB and two control groups: 284 elderly men from an ongoing cohort from our department, and 151 postmenopausal women seen in our outpatient clinic for routine medical evaluation. Results: The mean \pm SD serum $25-\mathrm{OHD}$ was significantly lower in subjects with PDB $(23.76 \pm 6.29 \mathrm{ng} / \mathrm{mL})$ than in the control groups of elderly men $(27.86 \pm 13.52 \mathrm{ng} / \mathrm{mL})$ and postmenopausal women $(30.30 \pm 9.59 \mathrm{ng} / \mathrm{mL}), p=0.015$. The prevalence of vitamin $D$ deficiency considering a cut-off point of serum $25-\mathrm{OHD}<30 \mathrm{ng} / \mathrm{mL}$ was $85.7 \%$ in patients with PDB, and in elderly men and postmenopausal women it was $66.7 \%$ and $54.3 \%$, respectively $(p<0.001)$. Conclusion: These results suggest a high prevalence of hypovitaminosis D in patients with Paget's disease living in the tropics. Arq Bras Endocrinol Metab. 2013;57(7):509-12
\end{abstract}

\section{Keywords}

Paget's disease of bone; vitamin D deficiency; secondary hyperparathyroidism; osteitis deformans

\section{RESUMO}

Objetivo: Investigar se a deficiência de vitamina D é mais prevalente nos pacientes com doença de Paget óssea (DPO) do que em controles equiparados pela idade. Sujeitos e métodos: Neste estudo retrospectivo avaliamos a 25-OHD em 28 pacientes não tratados com DPO e dois grupos controle: 284 homens idosos de uma coorte de nosso departamento e 151 mulheres na pós-menopausa atendidas em nosso ambulatório para avaliação médica de rotina. Resultadlos: A média \pm DP da 25-OHD foi significativamente menor em indivíduos com DPO $(23,76 \pm 6,29 \mathrm{ng} / \mathrm{mL})$ do que nos grupos controle de homens idosos $(27,86 \pm 13,52 \mathrm{ng} / \mathrm{mL})$ e de mulheres na pós-menopausa $(30,30 \pm 9,59 \mathrm{ng} / \mathrm{mL})$, $p=0,015$. A prevalência de deficiência de vitamina $D$, considerando um ponto de corte $<30 \mathrm{ng} / \mathrm{mL}$, foi de $85,7 \%$ em pacientes com DPO e, em homens idosos e mulheres na pós-menopausa, foi de $66,7 \%$ e $54,3 \%$, respectivamente $(p<0,001)$. Conclusão: Esses resultados sugerem uma alta prevalência de hipovitaminose D em pacientes com DPO nos trópicos. Arq Bras Endocrinol Metab. 2013;57(7):509-12

\section{Descritores}

Doença de Paget óssea; deficiência de vitamina D; hiperparatireoidismo secundário; osteíte deformante
1 Divisão de Endocrinologia, Diabetes e Doença Óssea, Hospital Agamenon Magalhães, Universidade de Pernambuco (UPE), Recife, PE, Brazil ${ }^{2}$ Departamento de Saúde Pública e Epidemiologia, Universidade Federal de Pernambuco (UFPE), Centro de Pesquisas Aggeu Magalhães, Fundação Oswaldo Cruz, Recife, PE, Brazil
Correspondence to: Luiz Griz

Estrada das Ubaias, 332/302, Casa Forte

52061-080 - Recife, PE, Brazi luizgriz@globo.com

Received on Aug/26/2012 Accepted on Dec/5/2012

\section{INTRODUCTION}

$\mathrm{V}$ itamin $\mathrm{D}$ deficiency has long been known to cause osteomalacia, falls, osteoporosis, and fractures. Vitamin D is a fat-soluble vitamin and is obtained from skin irradiation and limited dietary sources. Vitamin D from the skin and diet is metabolized in the liver to 25-hydroxyvitamin D (25-OHD), which has a long half-life, and is the major circulating metabolite and marker of vitamin D status $(1,2)$. In the kidney, 25-OHD is metabolized by the enzyme 25 -hydroxyvitamin D-1(alpha)-hydroxylase (CYP27B1) to its active form, 1,25-dihydroxyvitamin $\mathrm{D}$. The mechanism of action of the active form of vitamin $\mathrm{D}$ is similar to that of other steroid hormones and is mediated by its binding to vitamin $\mathrm{D}$ receptor (VDR). 
It has been suggested that vitamin $\mathrm{D}$ deficiency should be defined as 25-OHD below $20 \mathrm{ng} / \mathrm{mL}$; insufficiency as $25-\mathrm{OHD}$ of $21-29 \mathrm{ng} / \mathrm{mL}$; and sufficiency as 25-OHD of $30-100 \mathrm{ng} / \mathrm{mL}$ (3).

Paget's disease of bone was first described by Sir James Paget (4). It is a focal, progressive disorder of bone remodeling (5). Initially, there is excessive osteoclastic bone resorption followed by a secondary increase in osteoblastic activity, leading to pain, fractures, and deformities. The main sites affected are the vertebrae, long bones, pelvis, and the skull (6).

The role of vitamin D metabolism in Paget's disease of bone has not been well defined yet. There is evidence of an inverse correlation between the severity of Paget's disease, as measured by plasma alkaline phosphatase levels and 25-OHD (7), and we know that 25-OHD levels are inversely associated with parathyroid hormone levels, resulting in secondary hyperparathyroidism, which is a potentially harmful condition, especially in patients already suffering from another bone disease, such as Paget's disease of bone.

In this study, our purpose was to compare serum 25-OHD levels in a group of patients with untreated Paget's disease of bone with age-matched control subjects.

\section{SUBJECTS AND METHODS}

We studied 28 untreated patients (14 men and 14 female) with Paget's disease of bone diagnosed at our institution between October 2010 and April 2012, who were compared with two age-matched control groups, 284 elderly men and 151 postmenopausal women. The control group of elderly men was recruited from an ongoing cohort in our institution, and the one comprising postmenopausal women were patients seen in our endocrine outpatient clinic for routine medical evaluation. The diagnosis of Paget's disease was established by the finding of increased activity of serum alkaline phosphatase, characteristic radiographic features, and radionuclide scanning. Neither the patients with Paget's disease nor the controls were taking vitamin D supplementation.

Serum calcium, albumin, and alkaline phosphatase were measured using an autoanalyzer (Cobas-Mira Plus, Roche, Basel, Switzerland). Serum PTH was assessed by automated electrochemiluminescence Elecsys - Roche Diagnostics Gmbh, Mannheim, German), and serum 25-OHD was measured by electrochemilumines- cent immunoassay (DiaSorin-Liaison). The sensitivity of this assay, defined as the lowest quantity different from zero, is $2 \mathrm{ng} / \mathrm{mL}$, and the intra-and interassay coefficients of variation were 4 and $6 \%$, respectively. We considered vitamin D deficiency when serum 25-OHD levels were below $30 \mathrm{ng} / \mathrm{mL}$.

The study was approved by the Agamenon Magalhães Hospital Ethics Committee.

\section{Statistical analysis}

The results were analyzed using means, standard deviations, and percentages. The F test (Anova) with Tukey and Tamhane comparisons, and the Pearson chi-squared were used. $\mathrm{P}$ values lower than 0.05 indicated a significant difference.

\section{RESULTS}

The mean \pm SD serum 25-OHD was significantly lower in subjects with untreated Paget's disease (23.76 $\pm 6.29 \mathrm{ng} / \mathrm{mL}$ ) than in the control groups: $27.86 \pm$ 13.52 (elderly men) and $30.30 \pm 9.59$ (postmenopausal women).

The prevalence of vitamin $\mathrm{D}$ deficiency, considering a cut-off point of serum 25-OHD concentration < $30 \mathrm{ng} / \mathrm{mL}$, was $85.7 \%$ in patients with Paget's disease, while in the elderly men and postmenopausal women it was $66.7 \%$ and $54.3 \%$, respectively $(\mathrm{p}<0.001)$. The clinical and laboratory characteristics of the patients with Paget's disease of bone and the control groups are shown in Table 1.

In spite of a tendency $(\mathrm{p}=0.07)$ in our study, no significant correlations were found between 25-OHD and plasma alkaline phosphatase in patients with Paget's disease. Most of the patients with Paget's disease were symptomatic $(60.7 \%)$ and the most affected skeletal areas were the pelvis, long bones of the lower extremities, vertebrae and skull, and the prevalence of secondary hyperparathyroidism considering a cutoff value of serum 25 -OHD less than $25 \mathrm{ng} / \mathrm{mL}$ was $17.2 \%$ ( 5 patients).

\section{DISCUSSION}

This was the first study on vitamin D status in subjects with untreated Paget's disease of bone compared with age-matched control conducted in Latin America. Occult vitamin $\mathrm{D}$ deficiency has been reported in 
Table 1. Clinical and laboratory data of patients with $\mathrm{PDB}^{\star}$ and control patients

\begin{tabular}{|c|c|c|c|c|c|c|}
\hline \multirow[t]{2}{*}{ Variable (Mean \pm SD) } & \multicolumn{3}{|c|}{ Group } & \multirow[b]{2}{*}{$\mathrm{p}$ value } & \multirow{2}{*}{$\begin{array}{l}\text { Elderly men + } \\
\text { postmenopausal } \\
\text { women }\end{array}$} & \multirow[b]{2}{*}{$P$ value } \\
\hline & PDB & Elderly men & $\begin{array}{l}\text { Postmenopausal } \\
\text { women }\end{array}$ & & & \\
\hline & $(n=28)$ & $(n=279)$ & $(n=151)$ & & $(n=430)$ & \\
\hline Age (years) & $67.36 \pm 9.72$ & $69.48 \pm 6.49$ & $67.87 \pm 5.24$ & $\mathrm{p}^{(1)}=0.021^{\star *}$ & $68.92 \pm 6.16$ & $p^{(4)}=0.409$ \\
\hline Body mass index $\left(\mathrm{kg} / \mathrm{m}^{2}\right)$ & $25.41 \pm 4.20$ & $25.68 \pm 4.32$ & $28.05 \pm 4.87$ & $\mathrm{p}^{(2)}<0.001^{\star \star}$ & $26.51 \pm 4.65$ & $p^{(5)}=0,222$ \\
\hline Serum 25-OHD (ng/mL) & $23.76 \pm 6.29$ & $27.86 \pm 13.52$ & $30.30 \pm 9.59$ & $\mathrm{p}^{(1)}=0.015^{\star \star}$ & $28.72 \pm 12.32$ & $p^{(4)}=0,001^{* *}$ \\
\hline \multicolumn{7}{|l|}{ Serum 25-OHD (ng/mL) n (\%) } \\
\hline$<30$ & $24(85.7)$ & $186(66.7)$ & $82(54.3)$ & $\mathrm{p}^{(3)}<0.001^{\star *}$ & $268(62.3)$ & $\mathrm{p}^{(3)}=0,013^{* *}$ \\
\hline$\geq 30$ & $4(14.3)$ & 93 (33.3) & 69 (45.7) & & $162(37.7)$ & \\
\hline
\end{tabular}

* Paget's disease of bone; ${ }^{* *}$ Significant difference at $5.0 \%$.

(1): using the F test (ANOVA) with Tamhane comparison; (2): using the F test (ANOVA) with Tukey comparison; (3): using Pearson chi-square; (4): using the t-Student test with unequal variance; (5): using the t-Student test with equal variance.

various situations, particularly in elderly persons. Our data showed a high prevalence of hypovitaminosis $\mathrm{D}$ in untreated patients with Paget's disease (85.7\%), higher than in our age-matched control groups of postmenopausal women $(54.3 \%)$ and elderly men (67.7\%). In another study conducted in the city of Recife (8), the prevalence of hypovitaminosis D in 627 postmenopausal women was $43 \%$ when a cut-off point of serum 25-OHD less than $25 \mathrm{ng} / \mathrm{mL}$ was used.

Decreased exposure to sunlight is expected in patients with disability, and could be the reason for a higher prevalence of vitamin D deficiency, but none of our patients with Paget's disease had any physical disability. Recife is situated at latitude $10^{\circ} S$ and has sunny weather throughout the year. Although we have not performed any sun exposure evaluation in the patients with Paget's disease, sun exposure was studied in the group of elderly men, and a high prevalence of hypovitaminosis $\mathrm{D}$ was found, despite the high sun exposure during the summer months (9).

Another possible explanation is the high body mass index (BMI). It is known that serum 25-OHD levels are lower in subjects with high BMI than in those with normal BMI, but BMI in the subjects with Paget's disease was not higher than in the control groups. A further possibility is that the differences in age might provide an explanation for differences in $25-\mathrm{OHD}$, but the ages of the Paget's disease patients and the aged-matched controls were very similar. Other possible causes of the lower serum 25-OHD levels in the Paget's disease patients could be the decreased serum 25-OHD production or enhanced hepatic catabolism, or an increased consumption of 25-OHD by the pagetic bone, owing to the high bone turnover in these subjects.
In an English study, 25-OHD serum values in 32 patients with Paget's disease were significantly lower than in the 32 age-matched control subjects, and there was a significant correlation between alkaline phosphatase activity and $25-\mathrm{OHD}$ values $(\mathrm{p}<0.05)(10)$. In spite of such a tendency $(\mathrm{p}=0.07)$ in our study, we did not find any significant inverse correlation between serum levels of 25-OHD and alkaline phosphatase, which may be because the mean serum 25-OHD in the patients with Paget's disease from the English study (mean $25-\mathrm{OHD}=11.32 \mathrm{ng} / \mathrm{mL}$ ) was lower than our patients with Paget's disease (mean 25-OHD $=23.76 \mathrm{ng} / \mathrm{mL}$ ).

25-OHD levels are inversely associated with PTH, resulting in secondary hyperparathyroidism, which is associated with bone loss and consequent increased risk of fractures. The prevalence of secondary hyperparathyroidism in patients with Paget's disease was evaluated in an US study (11). A total of 30 patients were either untreated or had received no treatment for 6 months or longer when studied; the other 9 were receiving either salmon calcitonin (3) or etidronate (6). The results showed that, in 7 of the 39 patients (18\%), parathyroid hormone levels were increased above normal. This prevalence was similar to that found in our patients with Paget's disease (17.2\%).

In conclusion, we found a high prevalence of hypovitaminosis D in untreated patients with Paget's disease of bone living in the tropics. Considering that vitamin D deficiency is associated with secondary hyperparathyroidism and serum 25-OHD levels can be lower in subjects with Paget's disease of bone, thus compromising the efficacy of bisphosphonate, the agent of choice for the treatment of Paget's disease, we suggest that the levels of 25-OHD should be restored prior to the use 
of bisphosphonates, and that these patients be treated with doses of vitamin $\mathrm{D}$ higher than those employed in the treatment of osteoporosis.

Disclosure: no potential conflict of interest relevant to this article was reported.

\section{REFERENCES}

1. Holick MF. Resurrection of vitamin D deficiency and rickets. J Clin Invest. 2006;116:2062-72.

2. Deluca HF. Overview of general physiologic features and functions of vitamin D. Am J Clin Nutr. 2004;80:1689S-96S.

3. Holick MF. Vitamin D deficiency. N Engl J Med. 2007;357:266-81.

4. Paget J. On a form of chronic inflammation of bone (osteitis deformans). Med Chir Trans. 1877;60:37-64.

5. Kanis JA. Pathophysiology and treatment of Paget's disease of bone. London, U.K: Carolina Academic Press, Martin Dunitz; 1991.
6. Bandeira F, Caldas G, Griz L, Macedo G, Marinho C, Bandeira C. Paget's disease of bone-Characteristics of 49 patients from a single institution in Recife, Brazil. J Bone Miner Res. 1999;14(1):S539.

7. Devlin RD, Gutteridge DH, Prince RL, Retallack RW, Worth GK. Alterations in vitamin D metabolites during treatment of Paget's disease of bone with calcitonin or etidronate. J Bone Miner Res. 1990;5:1121-6.

8. Bandeira F, Freese E. Occult vitamin D deficiency and its relationship with bone mineral density among postmenopausal women in Recife, Brazil. J Bone Miner Res. 2003;18(2):S407.

9. Cabral M, Borges C, Fontan D, Bandeira L, Chaves N, Bandeira F. Prevalence of vitamin $D$ deficiency and its relationship with sun exposure and skin phototype in elderly men living in the tropics. J Bone Miner Res. 2011;26(1):S-524.

10. Guillard-Cumming DF, Beard DJ, Douglas DL, Johnson SK, Lawson-Matthew PJ, Russell RG, et al. Abnormal vitamin D metabolism in Paget's disease of bone. Clin Endocrinology (Oxf). 1985;22(4):559-66.

11. Siris ES, Clemens TP, McMahon D, Gordon A, Jacobs TP, Canfield RE. Parathyroid function in Paget's disease of bone. J Bone Miner Res. 1989;4(1):75-9. 